\title{
David Oliver: A fairy tale mandate for the NHS
}

Just after the 2010 UK election, when I was still seconded to the Department of Health, the new English health secretary, Andrew Lansley, came to meet the department's doctors to set out his vision for the NHS. This led to the Health and Social Care Act 2012, now widely regarded as a costly and needless disruption lacking electoral mandate. ${ }^{1}$

Ironically, a different mandate was part of this vision. Lansley stated that the health secretary should have a hands-off relationship with operational management of the NHS, which would no longer be run from Whitehall but through arm's length bodies, notably NHS England. He would simply issue a mandate for the outcomes the service was to achieve and would leave process alone. $^{2}$

Lansley left in 2012, his original vision much altered. ${ }^{13}$ But the first NHS mandate between the government and NHS England was issued. ${ }^{4}$

The mandate seems more a cosmetic exercise now. Lansley's successor, Jeremy Hunt, has been far from "arm's length," intervening often in the NHS's operations. But the draft mandate for 2016-20 is out for consultation until 23 November. ${ }^{5} \mathrm{~A}$ window into the soul of this government's health team, it prioritises preventing ill health and supporting healthier lives; safety, quality, and seven day services; maintaining both performance and financial balance; making out-of-hospital services more integrated and accessible; and efficiency and productivity.

These may seem like goals we could all support, although I'd suggest that seven day services need to start with urgent and emergency care before we start pushing the same staff to provide routine and elective work at all hours.

In the past two weeks the chief executives of the think tanks the Nuffield Trust, the Health Foundation, and the King's Fund cosigned a letter making it clear that the NHS was under serious financial and performance stress and that urgent services would struggle to cope this winter. ${ }^{6}$ NHS England's chief executive, Simon Stevens, also called for the proposed additional $£ 8 b n$ ( $€ 11.4 \mathrm{bn} ; \$ 12.2 \mathrm{bn}$ ) to be released early in the parliament before "the rubber hits the road." "

Few commentators think that the proposed $£ 22$ bn NHS savings alluded to in the mandate are deliverable. And even deeper social care cuts are bound to hit NHS performance further. ${ }^{8}$ Public health budgets have been cut, making a mockery of the commitment to prevention. ${ }^{9}$ Workforce crises affect nursing, ${ }^{10}$ general practice, ${ }^{11}$ and emergency medicine. ${ }^{12}$

The draft mandate is but a fairy tale. It asks us to deliver safer, better, more integrated services for more days with inadequate funding and staff numbers, and all before the next election. I hope that the consultation receives some robust feedback before it closes on 23 November.

Competing interests: I have read and understood the BMJ policy on declaration of interests and have no relevant interests to declare.

Provenance and peer review: Commissioned; not externally peer reviewed.

Follow David on Twitter, @mancunianmedic

1 Timmins N; King's Fund, Institute for Government. Never again? The story of the Health and Social Care Act 2012. Jul 2012. www.instituteforgovernment.org.uk/sites/default/files/ publications/Never\%20again_0.pdf.

2 Department of Health. Equity and excellence: liberating the NHS. Jul 2010. www.gov.uk/ government/uploads/system/uploads/attachment_data/file/213823/dh_117794.pdf.

3 Field S; NHS Future Forum. Summary report on proposed changes to the NHS. 13 Jun 2011. www.gov.uk/government/uploads/system/uploads/attachment_data/file/213748/ dh_127540.pdf.

4 Department of Health. The NHS Mandate. 13 Nov 2012. www.gov.uk/government/ publications/the-nhs-mandate.

5 Department of Health. A consultation on the government's mandate to NHS England to 2020. Oct 2015. www.gov.uk/government/uploads/system/uploads/attachment_data/file/ 472043/final_consultation_doc.pdf.

6 Donnelly L. NHS winter crisis now inevitable, as think tanks warn of potential waiting list deaths. Telegraph 2015 Nov 14. www.telegraph.co.uk/news/nhs/11991224/NHS-wintercrisis-now-inevitable-think-tanks-warn.html.

7 Donnelly L. Simon Stevens: NHS could run out of cash without a boost. Telegraph 2015 Nov 9. www.telegraph.co.uk/news/health/news/11984078/Simon-Stevens-NHS-couldrun-out-of-cash-without-a-boost.html.

8 Humphries R, Appleby J; King's Fund. Social care: a future we don't yet know. 8 Nov 2015. www.kingsfund.org.uk/blog/2015/11/social-care-future.

9 Buck D; King's Fund. Cuts to public health spending: the falsest of false economies. 6 Aug 2015. www.kingsfund.org.uk/blog/2015/08/cuts-public-health-spending-falsest-falseeconomies.

10 Eight out of 10 trusts admit they "face nursing shortages." Nurs Times 2014 May 16. www. nursingtimes.net/roles/nurse-managers/eight-out-of-10-trusts-admit-they-face-nursingshortages/5070928.fullarticle.

11 Duffin C. Half of GP training places "unfilled in some areas." Pulse 2015 Jul 21. www. pulsetoday.co.uk/your-practice/practice-topics/education/half-of-gp-training-places-unfilledin-some-areas/20010555.fullarticle.

12 General Medical Council. Medical education's front line: a review of training in seven emergency medicine departments. Jul 2013. http://bit.ly/1QJeak8.

Cite this as: BMJ 2015;351:h6203

๑ BMJ Publishing Group Ltd 2015 